\title{
Democracy and the new High School
}

\section{Tuca Henrique Verçosa Carneiro de Andrade ${ }^{1 *}$; Maria Eduarda Verçosa Carneiro de Andrade ${ }^{2}$; Ione Teresinha Oliveira Leitão ${ }^{3}$}

1 Graduated in History from UFPE, Master's degree in Education from PPGEdu - UFPE.

2 Graduated in Economics from UFPE, Master's student in Computer Science - UFPE.

3 Master's degree in education from the Ibero-American University Foundation - FUNIBER.

E-mail adresses: tucavercosa@hotmail.com (Tuca Henrique Verçosa Carneiro de Andrade), eduardavercosa@hotmail.com (Maria Eduarda Verçosa Carneiro de Andrade), ione.teresinhal@gmail.com (Ione Teresinha Oliveira Leitão)

${ }^{*}$ Corresponding author

\section{To cite this article:}

Andrade, T.H.V.C.; Andrade, M.E.V.C.; Leitão, I.T.O. Democracy and the new High School. International Journal of Sciences. Vol. 2 , No. 3, 2021, pp. 66-70. ISSN 2763-5392.

Received: 10 14, 2021; Accepted: 10 15, 2021; Published: 11 03, 2021

\begin{abstract}
The Reform of High School, although part of a moment of democratic rupture in our country, is part of a much greater conjuncture, that of neoliberalism. Globalization is responsible for a process of structural changes in society, in labor relations and in the capacity of the State to promote public policies for the guarantee of social rights. It is possible to analyze the Reform of High School and its economic view of education from different angles. The present work seeks to smooth the reform of high school in the light of neoliberal reforms in education from the bias of professionalization, curriculum and democracy. This is a study with data collection from secondary sources, through bibliographic survey in the following databases: Google Academic and Scientific Electronic Library Online (SciELO). In Brazil, neoliberal proposals for education begin to gain ground in the period of the business-military dictatorship, but it is from the New Republic that these ideas gain strength, including in left-wing governments. The constitution of high school after retirement is divided into two parts: a part common to all, which extends through the three years of high school, having as compulsory subjects in the three years only Portuguese, Mathematics and English, being complemented by the other subjects in a non-compulsory way in the three years. The curricular homogenization proposed by the BNCC, which determines not only what should be seen in the room, but also the order, the form and the days, are only justified from the logic of control. There is always resistance, there are always resignifications and adaptations at the local level, where these policies effectively materialize. It is on the classroom floor that policies are, or are not, put into practice.
\end{abstract}

Keywords: High school reform. Neoliberalism. Curriculum. Democracy. Professionalization.

\section{Introduction}

It is known by all that education is not owed to the social context in which it is inserted. Thus, we understand that to analyze the relationship between the current High School Reform - law 13.415/2017 - and democracy is fundamental to understand the social context in which the reform developed. However, it would be misleading to believe that this context is the result of only a national conjuncture. We say this because we believe that the Reform of High School, although part of a moment of democratic rupture in our country, is part of a much greater conjuncture, that of neoliberalism (NOSELLA,2016).

Therefore, we need to begin to present how neoliberalism influences education and then relate this neoliberal expectation to political events in Brazil and to the Reform of High School. For authors such as Perry Anderson (1995) and Márcia Ângela Aguiar (2019) globalization is responsible for a process of structural changes in society, in labor relations and in the state's ability to promote public policies for the guarantee of social rights.

We know that the Neoliberal State that replaces the Welfare State seeks to reduce the State in the level of social rights and makes it the great guarantor of the profit of capital. For this, neoliberalism advocates the flexibilization of social rights - such as labor, social security and others. We are particularly interested in the impact of this flexibilization on 
labor relations, which are increasingly deregulated in favor of the capital, including in times of pandemic, such as the new Coronavirus - flexibilization means scrapping (SANTOS, 2020; ANTUNES, 2020).

This relationship with the labor market is fundamental because in neoliberal times education has the preponderant function, not to say exclusively, of preparing for the labor market (LAVAL, 2019; FREITAS, 2018, NOSELLA, 2016, PARO, 1999). This preparation for work is not for any work, but preparing for work without rights, scrapped, preferably where each is an entrepreneur of himself, being each responsible for himself, not holding the State accountable - for his omission in relation to rights; and not questioning the capital and the precarious work he offers (SAVIANI 2018).

In other words, the neoliberal paradigm holds the individual accountable for their condition of misery. It is needed technical workers, not questions of labor relations. Thus, the State omission and resonating from responsibility leaves public education to its own devices and this, without investments or structure, is not able to offer a quality education, being therefore demoralized, questioned, taxed as inefficient. This demoralization of the public school seeks to convince minds and hearts of the need for privatization of public education, since the private system is the example of efficiency and effectiveness (PARO, 1999).

It is possible to analyze the Reform of High School and its economic view of education from different angles. In this text, the proposal is to analyze the Reform of High School in three aspects: with regard to democracy, with regard to the curriculum and with regard to preparation for the labor market - professionalization. It is therefore necessary to contextualize the reform itself (SÜSSEKIND, 2018).

The present work aims to analyze the reform of high school in the light of neoliberal reforms in education, based on the bias of professionalization, curriculum and democracy.

\section{Methodology}

This is a study with data collection from secondary sources, through a bibliographic survey and based on the experience experienced by the authors at the time of an integrative review.

For the survey of articles in the literature, a search was conducted in the following databases: Google Academic and Scientific Electronic Library Online (SciELO). As an exclusion criterion, articles in English and Spanish were excluded.

\section{Results and Discussion}

\subsection{To reflect on the Reform}

In Brazil, neoliberal proposals for education begin to gain ground during the period of the business-military dictatorship, but it is from the New Republic that these ideas gain strength, including in left-wing governments (SAVIANI, 2018). It is worth mentioning that in the times of the Workers' Party - PT the neoliberal paradigm experienced some setbacks, but nothing substantial.

In 2016 President Dilma Rousseff underwent an impeachment process, characterized as a parliamentary legal media coup, and assumes vice president Michel Temer as president. With this democratic rupture, made with the support of business sectors in Brazil, education is put up for sale and the Reform of High School is the first step in this sale of public education.

The Reform came to fruition with the approval of law $13.415 / 2017$, but the same reform had already entered into force since it was made from provisional measure, entering into force on the day of its publication and needing within 120 days to pass the approval of the National Congress. From the present moment it is clear the authoritarianism in the reform, made from the top down, without consulting the organizations of teachers, secretaries, without listening to students and without listening to universities and their associations.

It is important to remember that a reform was already being carried out for high school at the time of president Dilma Rousseff's administration. This reform, which did not happen, was being made with extensive listening to social movements, associations of teachers, students and universities. However, with the 2016 coup this reform was shelved and the neoliberal version was put into practice.

For Ramon de Oliveira (2020) "the reform was only done so quickly due to the fact that the "new High School" has already been built in the context of business thought" (p.12). For Márcia Ângela Aguiar (2019) the reform of high school is, in fact, a return of a conservative dimension of education that was in force in the days of Fernando Henrique Cardoso's government and which was harshly criticized by the academy.

We have the impression that we can summarize the High School Reform on three key points, including: control, flexibilization and homogenization. These points are relevant to the understanding of reform and its relations with neoliberalism and the business sectors of education. To understand the reform in these three points we will look at its consequences in the democratization of the school, in the curricula and in the professionalization.

The constitution of high school after retirement is divided into two parts: a part common to all, which extends through the three years of high school, having as compulsory subjects in the three years only Portuguese, Mathematics and English, being complemented by the other subjects in a noncompulsory way in the three years. To this common curriculum are separated 1,800 hours and from 2022 the time required for the completion of optional training itineraries, chosen by the students, will be 2400 hours.

Thus, all students will attend a common trunk of 1800 hours divided in the three years of high school, which represents a reduction in general education, since in the previous model this training was 2400 hours. The training itineraries - in one of the five areas: applied human and social sciences, languages, mathematics, nature sciences, mathematics or professional technical training - should, from the choice of students occupy the other 2400 hours of the curriculum, preferably with activities outside the school, since bncc opens a gap for courses and other activities outside the school to be counted as workload (BRASIL, 2017).

At the point of flexibilization, the reform of high school indicates that it seeks to port in high school more attractive to 
young people, to this end, the new configuration of high school will give young people the possibility to choose which areas of knowledge will deepen. The speech is very clear, gives students the possibility to choose which itinerary to take is a democratic practice of education. At least that's what educational reformers say.

However, the reform of high school by dealing with this flexibility in a generic way leaves a gap for a "everything is possible", so schools are not obliged to offer all training itineraries. With this, this choice will be realized only for those who are from private schools. After all, freedom is the domination of those who hold economic power in society.

Understanding that the right to education is a subjective public right and that non-access to quality education is the non-right to education, we can understand that the neoliberal concept of education is an exclusionary concept that boils down to: "quality education for those who can afford and quality education for those who depend on the State". To seek to dress public education with modern airs, the reformers propose to implement in the school the marketing logic, which is a logic of individualism and competitiveness.

Thus, more and more the public school is no longer seen and understood as a public place, being at the mercy of capital. Jaques Rancière tells us that today a democracy is built that is that of the narcissistic consumer in a society commanded by the law of consumer individuality (2014, p.35).

It is clear that the proposal of the new high school, by impoverishing the intellectual formation of young people seeks to throw them more and more in the wheel of capital. We have a teaching that stimulates competitiveness and individualism, fundamental characteristics for the reproduction of neoliberal capitalism.

This individualism is a risk to democracy and to the democratic management of the school, since students can be formed for their personal achievement and not for community achievements (RANCIÈRE, 2014), thus transforming that it is public in private (Idem, idem). It is clear that the neoliberal school seeks to form for individualism and competition, hence the great emphasis it places on large-scale evaluations (SAVIANI, 2018; FREITAS, 2018, GONÇALVES, 2017).

The school managed from the interests of capital is not a place of discussion of local problems, with a serious reversal of roles. The school, which should be the locus of socialization and democratic practice, becomes the place of the search for efficiency in a logic of total quality. Students, teachers, institutions themselves see themselves as competitors, seek only their interests, which are ultimately the interests of capital and not of these subjects.

This context presented leads us to the second proposed path, to look at reform from the perspective of the curriculum. The reform of high school is also realized in another legal institutional device that is the Common National Curriculum Base - BNCC. This objective is to be a reference for the country's high school curricula. Márcia Ângela Aguiar (2019) will indicate that BNCC is oriented towards the development of skills, indicating what students should know and, above all, what they should know how to do (p.8).
The curricular homogenization proposed by the BNCC, which determines not only what should be seen in the room, but also the order, the form and the days, is only justified from the logic of control. We know that the curriculum is a field of disputes and resistances (LOPES \& BORGES, 2017). It is exactly this possibility of resisting that the BNCC wants to withdraw, since it determines which, how and when the content will be seen; and that content will be charged on largescale assessments.

Here is another vector of privatization of the public school, which will increasingly need teacher training, handouts, booklets and a number of other materials and services produced and sold by the private sector. We should, however, pay to what Ramos et al (2011) states that even though the curriculum is a place of dispute, it is only a provisional fixation, even after its legalization.

The new curriculum proposed by BNCC is visibly dominated by performability, by managerialism, which seek to master practice. The BNCC's need for everyone to learn everything at the same time is only sustained to ensure that students are prepared for large-scale assessments. It is a deception to want everyone to learn within a hegemonic stability of the curriculum.

This hegemonic stability is only of interest to capital and its reproduction with the help of education. Therefore, we have reached the last perspective worked on in this text, which is professionalization. The new High School has, at least from the official point of view, the intention of modernizing the last phase of basic education, for this it proposes a flexibilization that, as has been said, creates a school for the rich and a school for the poor, aggravating educational and social inequalities in Brazil.

The new high school and its BNCC seek to train the productive citizen, after all, in the era of neoliberalism and marginalized is the unproductive (SAVIANI, 2018a, p.11). So everyone needs to be productive! For the children of the working class, it is sought to offer a fast productivity, which is realized in employment soon after, or even during high school - if it offers a technical training.

We have seen earlier that one of the five optional training itineraries is that of technical training. Remembering that schools are not obliged to offer all areas of itineraries we can deduce that there will be a preponderance of the offer of the itinerary of a technical nature, since: there is no need for a teacher with specific training, only with notorious knowledge; part of this training can be given outside schools, in parallel courses - which, for reform can count as workload.

This reality of the new high school seeks to train to perform low quality jobs, low salaries and without protection. Ramon de Oliveira (2015) relates professional education, to the lines offered by the new high school, with the process of precarious work. For the author, youth - poor - still needs to work when in basic education and the recent professionalization of this youth can keep it away from continuing studies, since by necessity it will need to work.

The same author makes it clear that "current policies aimed at the youth sectors reinforce the process of precarious 
work" (2015, p.259). Thus, it seeks to offer a light and noncritical formation for those who have carried out the precarious work of society, because they do not need to think, but only to perform that activity. Within the neoliberal logic the young worker has his right to education denied and should still thank for having a precarious job.

Oliveira (2020) explains that the current reform of high school seeks to present as a solution to the problems of youth - daughter of the working class - the conception "according to which early vocational training is the solution to end the situation of poverty experienced" (p.5). We see that the "new" high school seeks to train cheap labor to meet the interests of the account capital, blaming young people for their failure.

The high school assumes only a certifying characteristic for this youth, since it goes through high school in search of a certificate to occupy the jobs and technical level that are available - it should be remembered that there is no guarantee of employment, only the possibility of employability. This new high school stimulates competition, competitive citizenship, inequality.

Inequality is justified and a system is created (New High School) to perpetuate these inequalities, throwing the weight of "failure" on the backs of those who are, for the sake of the truth, the victims - the working-class youth who are attending high school. This system perpetuates inequality by impoverishing the curriculum and homogenizing it poorly for the poor; presenting, to the poor, a technical education such as general salvation; and emptying the collective sense of democracy, as it stimulates narcissistic individualism.

\section{Conclusions}

We saw the return of technicality as the whole force in Brazilian education from the High School Reform, law $13.415 / 2017$. The triad of control is due to the homogenization of the curriculum and large-scale evaluations and its consequences for Brazilian education are harmful as we well know. As Saviani (2018a) reminds us of the "technicist pedagogy, it would be said that it is the process that defines what teachers and students should do and, so too, when and how they will do it" (p.11).

It seeks complete control of the teachers' action, emptying teachers from the preparation of the contents to be seen - via BNCC and large-scale evaluations. We've seen the impoverishment of high school. But we also watch and a lot of resistance and more resistance will come, that's for sure. For, the new high school reduces the democratic space of the school, reduces the education of the children of workers and reduces the autonomy of teachers.

The business reforms of education, put under way in Brazil with greater emphasis from the first governments in the new republic, aim at the commercialization of education, reduced from the category of right to the category of merchandise. To affect this reduction and meet market expectations, it is essential to promote the demoralization of public education, to this end, public education must be scrapping in several ways. Here we analyze three vectors of privatization, scrapping: the reduction of the democratization of the school, which increasingly seeks to stimulate the individual; the curriculum as an element of control of the action of teachers, serving as the basis for the control made by large-scale evaluations - such as the National High School Exam (ENEM) and PISA; and in reducing the quality of education for the popular classes, with a High School that stimulates educational dualism, because, from its flexibility it allows schools for the ruling classes and the upper middle classes to maintain a high quality standard and public schools, for the working class, are abandoned to luck, since there are no resources to offer various training itineraries, in other words, for the poor a poor education.

We must remember that the curriculum is an unfinished political process (RAMOS et al, 2011), including the one proposed by the new high school. Just as it is essential not to lose sight of the stranglehold of the quality of education is not in the very humanistic curriculum of high school, as the reformers want us to believe. The bottleneck lies in the precarious conditions of schools, the precarious nature of teaching work and the constant interference of large entrepreneurs, who seek to make education a new and profitable market (OLIVEIRA, 2015; OLIVEIRA 2020).

We noticed that the neoliberal reforms of the Brazilian state, implemented from the 1990s on, gained new momentum from 2016. The New Public Management (NGP) is even more assumed, not only for education, but for all the bureaucracy of the State. Brazil is consolidated as a management state (MARQUES; Mendes, MENDES, MARANHÃO, 2019) and the public sector begins to have as reference for its functioning the private sector, "subverting the modern foundations of democracy, that is, the recognition of social rights linked to citizen status" (DARDOT; LAVAL, 2016, p. 274).

The reform of high school and the new BNCC fit perfectly into the principles of NGP presented by Marques; Mendes and Maranhão (2019, p. 354), quoting Verger (2015). These principles are: "common curriculum standards, external evaluation of educational quality, funding of schools based on results, flexibility of hiring and dispensation by the school, remuneration of teachers based on criteria of merit and productivity" (idem, idem).

We believe that it is clear that the reform of high school and the new BNCC are expressions of neoliberalism and a new public management that seeks to reduce democratic spaces. To paraphrase Jaques Rancière, the modern democratic man is the avid competitor (2014), this competitor is increasingly inserted in the Age of Indices, increasing his need for competition. School and public services are no longer the places of solidarity and collective sentiment and increasingly become the place of competition and individualism, injuring democracy in death.

Finally, we do not fall into a tautological analysis of the effects of high school reform on the aspects presented, it is essential to make it clear that an educational policy is only really materialized in micropolitics. In other words, the effects of the reform will not be exactly as reformers think, as it is not possible to imagine a top-down imposition. There is always resistance, there are always resignifications and adaptations at the local level, where these policies effectively 
materialize. It is on the classroom floor that policies are, or are not, put into practice. Together with my voice to the National Confederation of Education Workers - CNTE, how much this calls everyone and everyone to intervene for the non-effectiveness of the "new" high school (CNTE, 2018, p.425) since this high school is actually the end of high school.

\section{References}

[1] AGUIAR, Márcia Ângela. Reformas Conservadoras e a "nova educação": Orientações hegemônicas no MEC e no CNE. Educação e Sociedade, Campinas, v.40, 2019.

[2] ANTUNES, Ricardo. Coronavírus: o trabalho sob fogo cruzado. São Paulo, Bomtempo, 2020.

[3] CNTE. Confederação Nacional dos Trabalhadores em Educação. Consequências práticas da BNCC e da reforma no Ensino Médio. Revista Retratos da Escola, Brasília, v.12, n.23, p. 413-425, jul./out. 2018.

[4] DARDOT, Pierre \& LAVAL, Christian. A nova razão do mundo: ensaio sobre a sociedade neoliberal. São Paulo, Boitempo, 2016.

[5] FREITAS, Luiz Carlos de. A reforma empresarial da educação: Nova direita, velhas ideias. Expressão Popular, São Paulo, 2018.

[6] GONÇALVES, Suzane da Rocha. Interesses mercadológicos e o "novo" ensino médio. Revista Retratos da escola, Brasília, v.11, n.20, p.131-145, jan./jun. 2017.

[7] LAVAL, Christian. A escola não é uma empresa: o neoliberalismo em ataque ao ensino público. $1^{\mathrm{a}}$ edição, Boitempo, São Paulo, 2019.

[8] LOPES, Alice Casimiro \& BORGES, Veronica. Currículo, Conhecimento e Interpretação. Currículo sem fronteiras, v.17, n.3, p. 555-573, set./dez. 2017.

[9] MARQUES, Luciana Rosa; MENDES, Juliana Camila; MARANHÃ̃O, Iágrici Maria de Lima. A nova gestão pública no contexto da educação pernambucana e a qualidade educacional. RBPAE, v. 35 , n. 2 , p. $351-367$, mai./ago. 2019.

[10] NOSELLA, Paolo. Ensino Médio à luz do pensamento de Gramsci. Alínea, Campinas, 2016.

[11] OLIVEIRA, Ramon de. Precarização do trabalho: a funcionalidade da educação profissional. Revista Diálogo Educação, Curitiba, v.15, n.44, p.245-266. 2015.

[12] OLIVEIRA, Ramon de. A reforma do Ensino Médio como expressão da nova hegemonia neoliberal. Educação Unisinos, 24, 2020.

[13] RAMOS, Aura Helena; BARREIROS, Débora; FRANGELLA, Rita de Cássia. Políticas de currículo e escola: Entre fluxos e negociações, 2011.

[14] ROCHA, Nathália Fernandes \& PEREIRA, Maria Zuleide. Base Nacional Comum Curricular: os discursos sobre a docência. Revista Retratos da escola, Brasília, v.13, n.25, p. 203-217, jan./mai. 2019.
[15] PARO, Vitor Henrique. Parem de preparar para o trabalho. Reflexões acerca dos efeitos do neoliberalismo sobre a gestão e o papel da escola básica. In. Trabalho, formação e currículo: para onde vai a escola, p. 101-121, 1999.

[16] SANTOS, Boaventura de Sousa. A cruel pedagogia do Vírus. Edições Almedina, Coimbra, Portugal. 2020

[17] SAVIANI, Demerval. Política Educacional no Brasil após a ditadura militar. Rev. HISTEDBR On-line, Campinas, v.18, n.2 [76], p. 291-304, abr./jun. 2018.

[18] SAVIANI, Demerval. Escola e Democracia. Autores Associados, $43^{\mathrm{a}}$ ed. rev. - Campinas, SP, 2018.

[19] SÜSSEKIND, Maria Luiza. A BNCC e o "novo" Ensino Médio: reformas arrogantes, indolentes e malévolas. Revista Retratos da Escola, Brasília, v.13, n.25, p.91-107, jan./mai. 2019. 